\title{
Making sense of grammatical variation in Norwegian
}

\author{
Marianne Brodahl Sameien, Eivor Finset Spilling \& Hans-Olav Enger ${ }^{1}$
}

\begin{abstract}
This study examines two examples of grammatical variation in Norwegian inflection, strong versus weak verb conjugation and affixal versus periphrastic adjective comparison. The main claim is that they are not as arbitrary as one may think, they rather indicate a division of labour. The strong verb inflection tends to be motivated not only by phonology, but also by semantics. The affixal and periphrastic adjective comparisons tend to be used with different sets of adjectives and for different semantic purposes. These observations support the Principle of Contrast, the idea that a difference in forms normally will relate to a difference in some kind of meaning.
\end{abstract}

Key words: inflection, semantics, verb conjugation, adjective comparison, Principle of Contrast

\section{Introduction}

\footnotetext{
${ }^{1}$ This paper is based on research carried out by the first author (section 2, cf. Nilsen 2012) and the second author (section 3, cf. Spilling 2012, Spilling \& Haugen 2013, 2014) during their MA studies, supervised by the third author, who also drafted this paper. The authors are jointly responsible. We wish to thank the workshop organisers, our audience, and, last but not least, the reviewers, for very valuable input.
} 
In the introduction to this volume, the editors suggest that the language users' choice of grammatical variants is "far from arbitrary but depends on a wide array of factors from various domains". This insight can be related to the Principle of Contrast, the idea that "speakers take every difference in forms to mark a difference in meaning" (Clark 1993: 64) when 'meaning' is construed so as to include sociolinguistic and stylistic variation. In other words, perfect synonymy is rare, not only in the lexicon, but also in the grammar. Sometimes, linguists may have been too quick to assume that grammatical variants are distributed in an essentially pointless and arbitrary way.

The two grammatical phenomena examined in this paper illustrate this. We examine two cases in Norwegian - verb conjugation (section 2) and adjective comparison (section 3). In both, 'allomorphy' has been preserved. At first sight, the two alternatives seem to be merely synonymous. Since the alternatives have been preserved through centuries, this seems to show how random grammatical variation can be. On closer inspection, however, this proves not to be the case; rather, both Norwegian cases indicate a 'division of labour'. Both examples indicate allomorphy being linked to other properties in the system, if 'only' as a tendency. That is a partial answer to a question posed by the editors: Apparently, "functionally equivalent variants can be observed to co-exist over centuries of time. The question is why in some cases formal variance is retained for such a long time instead of being discarded after merely a brief period of toleration".

Our focus is on motivation, on tendencies, not on hard and fast rules. But this should come as no surprise. Tendencies are considered perfectly legitimate in the philosophy of science, and there is no reason to expect language to behave more categorically than nature. As argued by Baayen \& Prado Martin (2005), sensitivity to probability may be intrinsic to human language. 
The paper is organised as follows: Section 2 deals with Norwegian verb conjugations; the main claim is that 'strong' and 'weak' conjugations are not entirely equivalent, in as much as the division of labour is partly motivated, not only by the phonological make-up of the verb (a well-known insight), but also by the semantics of the verb (which is a new point). Section 3 deals with adjective comparison, and the main claim there is similar: The main point is that periphrastic and affixal comparison, which traditionally have been seen as 'merely' variants of the same thing, are doing somewhat different jobs. They are used with (by and large) different sets of adjectives, and in part for different purposes. On the one hand, in 'metacomparison', when an entity is compared to itself with respect to two different properties, as in English He is more persuasive than (he is) nice, only periphrastic inflection is used. On the other hand, in 'absolute comparison', when a comparative is used even if an entity is not compared to another but rather to an imaginary standard - as in Norwegian en eldre mann, lit. 'an older man', actually denoting a younger man than en gammel mann 'an old man' - only affixal inflection is used. In section 4, conclusions are summarised.

\section{Verb conjugations}

\subsection{Introducing the data - and the issue}

In Norwegian, as in other Germanic languages (barring Afrikaans), there is a distinction between strong and weak verb conjugation. They appear to be 'functionally equivalent'. Some verbs - the majority - form their past tense by affixation, and we call them 'weak'. Others - a minority - do not, and we call them 'strong'. Most strong verbs (but not all, cf. sove in Table 1 below) form their past tense by vowel change. Some important conjugations (inflection classes) are illustrated in Table 1. For illustration, we use one of the two written varieties of 
Norwegian, viz. Nynorsk. A + sign has been inserted between stem and affix; this + does, of course, not belong to Nynorsk orthography. ${ }^{2}$

Table 1: Verbal inflection classes, written Nynorsk (inserted + marks border between stem and affix)

\begin{tabular}{|c|c|c|c|c|c|c|}
\hline $\begin{array}{l}\text { Name for } \\
\text { class }\end{array}$ & 'strong' & 'strong' & $\begin{array}{l}\text { 'kaste' } \\
\text { a-class }\end{array}$ & $\begin{array}{l}\text { 'kjøpe' } \\
\text { te-class }\end{array}$ & $\begin{array}{l}\text { 'bygge' } \\
\text { de-class }\end{array}$ & $\begin{array}{l}\text { 'nå' } \\
\text { 'short verbs' }\end{array}$ \\
\hline Gloss & 'find' & 'sleep' & 'throw' & 'buy' & 'build' & 'reach' \\
\hline Infinitive & finn $+e$ & sov+e & kast+e & kjøp+e & bygg+e & nå \\
\hline Present & finn & $s \varnothing v$ & kast+ar & kjøp+er & bygg+er & nå+r \\
\hline Past & fann & sov & kast+a & kjøp+te & byg+de & nå+dde \\
\hline $\begin{array}{l}\text { Supine } \\
\text { (past ptc) }\end{array}$ & funn+e & sov+e & kast+a & $k j \varnothing p+t$ & byg $+d$ & nå+dd \\
\hline
\end{tabular}

What class will a certain lexeme belong to? This question seems to involve a considerable learning task. The reason is that class membership is not strictly predictable. For illustration, consider two verbs that rhyme with bygge 'build', viz. tygge 'chew' and rygge 'back (a car)'. The former inflects as a strong verb. Its past tense is togg, without an affix, but with vowel change. By contrast, rygge inflects as a weak verb - not like bygge, but like kaste. Its past tense is rygga, without vowel change, but with an affix added. Examples like these are often adduced to support the idea that class membership involves considerable memorization, and hence is arbitrary.

However, it is well known that there are certain tendencies for verbs with particular phonological shapes to belong to particular classes. For example, a verb that contains the

\footnotetext{
${ }^{2}$ We use Nynorsk examples in Section 2, Bokmål examples in Section 3.
} 
derivational suffix -er will invariably inflect like kjøpe, while a verb that has three consonants after the stressed vowel in the onset will invariably inflect like kaste. Examples of the former include regulere 'regulate', implisere 'imply' (cf. the respective past tense forms regulerte, impliserte), examples of the latter include plystre 'whistle', harskne 'turn rancid' (cf. the respective past tense forms plystra, harskna).

While the two generalizations just mentioned know no exceptions, the normal state of affairs is that there are some exceptions to the generalizations that can be made. For example, some verbs that have two different consonants after the stressed vowel in the onset inflect like kaste, cf. spikre 'nail fast', feste 'fasten' (cf. the respective past tense forms spikra, festa), but some are strong, e.g. breste 'break', skjelve 'shiver, shake' (cf. brast, skalv), and some inflect like bygge, e.g. lenge 'lengthen' (cf. lengde). Many verbs with /i:C/ in the lexical root will inflect as strong, e.g. skrike 'scream', skrive 'write' (cf. skreik, skreiv), many inflect like kjфpe, e.g. like 'like', flire 'laugh; sneer' (cf. likte, flirte), and some like kaste, e.g. kike 'work hard with sth.; rub' (cf. kika).

Such examples illustrate that while there are regularities, they are usually not predictive in the strict sense, they are 'only’ tendencies (e.g. Venås 1967 \& 1974, Hagen 1994, Enger 1998, Bjerkan 2000); the phonological motivation does not determine the membership $100 \%$.

Apart from this, the strong-weak distinction is traditionally considered 'mere' allomorphy, in Norwegian as in other Germanic languages. Some might think of such inflection classes as theoretically uninteresting, for allomorphy is often dismissed that way. Perhaps one may say that to scholars that focus on syntax in particular, allomorphy of this kind seems unlikely to shed any light on Universal Grammar (cf. Chomsky 1986: 147). From a different point of view, one might interpret the apparent absence of categorical phonological motivation for inflection classes as arguments for 'morphology by itself'. In the wake of Aronoff (1994), much emphasis has been placed on inflection classes as examples of 'pure morphology', as 
'morphomes', showing that morphology cannot be reduced to syntax. The verb conjugations might seem to be a case in point.

However, such theoretical conclusions rely on the premise that the conjugations really do not serve any other purpose; that the distinction strong-weak is literally meaningless. It might be worth examining this premise closer first.

\subsection{The link with semantics}

If the distinction between strong and weak is without meaning, i.e., has no semantic correlation, then one would not expect strong and weak verbs to differ in terms of any semantic parameter. Yet on closer inspection, the facts tell a different story: Strong verbs more often denote momentaneous actions, and there seems to be a link between semantics and conjugation.

The label 'momentaneity' may need further explication. It is not a trivial task to decide what counts as momentaneous. Nilsen (2012) used the following criteria (taken from Vendler 1967 and Nicolay 2007):

a) It should be possible to give an exact point of time in response to the question when the verbal event took place.

b) The verb should not work well in sentences containing an adverbial of time denoting a longer period of time, such as $i$ timevis 'for hours', $i$ årevis 'for years'. If the verb does work well with such an adverbial, this must not be due to an iterative interpretation. (An example of an iterative would be Han hosta i timevis 'he coughed for hours'. While the act of coughing is momentaneous, this sentence forces on the verb an interpretation where a momentaneous act is repeated for a longer period of time.)

c) The action denoted by the verb should normally not be divisible into phases of a certain duration. 
For a concrete illustration, we consider the verb skvette 'jump from surprise; start' (Nilsen 2012: 33). As for (a) question about exact point of time can normally be answered easily $-d a$ skvatt jeg 'then I jumped from surprise'. As long as we exclude the iterative, the verb will not work well together with an adverbial denoting a longer period of time (b) (one cannot jump from surprise continually for hours), and the action denoted by the verb is normally not divisible into phases (c). Since skvette qualifies as momentaneous with respect to all three criteria, there is no doubt that the verb is momentaneous. Other examples of verbs that normally have a momentaneous meaning might include breste 'break' and dette 'fall' ${ }^{3}$

In other cases, it may be more difficult to decide whether a verb should be classified as momentaneous, partly because actions may be construed in different ways. For example, a verb such as falle 'fall' may combine with an adverbial as $i$ årevis 'for years' (I årevis har USAs anseelse falt i Midt- $\emptyset$ sten 'For years, the US standing has been falling in the Middle East'). However, it is rather marginal to use falle in this metaphorical way. It is normally possible to ask about the exact point of time for falle, and the action denoted by the verb is normally not divisible into phases. Thus, it makes good sense to classify the verb as momentaneous. The fact that the distinction is not always an easy one does not invalidate it. ${ }^{4}$

${ }^{3}$ These claims about what normally is momentaneous are admittedly based on our intuition.

${ }^{4}$ An anonymous referee raises an interesting problem, viz. whether it is "acceptable to classify the verbs based on one central meaning, even if secondary meanings point to other modes of action". The first part of our answer is based on an analogy. In the literature on gender assignment, it is a commonplace that some nouns have their gender assigned on the basis of their meaning. Yet many nouns are polysemous, so at least for some nouns, different meanings offer different motivations for potentially conflicting gender assignment. Enger (2010b: $683-84$ ) suggests as a working hypothesis that in such cases, it is the "core 
Given this background, Nilsen (2012) examined all simplex strong verbs in a good, authoritative dictionary, Nynorskordboka. ${ }^{5}$ Of the 211 verbs found, 53, i.e., $25.1 \%$ of the members may be said to denote momentaneous action. This result may be contrasted with the findings for a control group. The control group consisted of 200 weak verbs taken from Venås (1974), an older monograph on weak verb inflection in Norwegian. Venås lists roughly 1000 weak verbs; every fifth verb was included in the control group (see Nilsen 2012: 3 - 4 for some modifications and caveats). It turned out that in the control group, only $9 \%$ (18 out of 200 verbs) satisfy the same criteria. Thus, there is a statistically significant difference between strong and weak verbs on this point. Strong verbs more often denote momentaneous actions, and there seems to be a link between semantics and conjugation.

Admittedly, synchronic regularities that seem striking from the linguist's point of view, are not always equally striking from the native speaker's point of view. One way of meaning" that serves as the basis for gender assignment. This hypothesis is not entirely original; it is also implicitly prevalent in much of the gender literature. Seeing that gender assignment for nouns can work this way, we see no reason why inflection class assignment for verbs could not work in the same way. A second part of our answer would be that many analysts before us have indeed classified verbs according to one central meaning. For example, traditional classifications of verbs as 'in/transitive' are usually based on an intuition about prototypical cases.

${ }^{5}$ The delimitation to simplexes has been done because a non-simplex verb usually belongs to the same inflection class as its simplex 'base'. For example, befinne (seg) 'be, find oneself' inflects like finne, forkaste 'reject' inflects like kaste. Thus, inspecting non-simplex verbs would not have brought forward much independent evidence. 
'checking' a generalisation that seems promising from the linguist's armchair is by means of diachrony. Diachronic changes go through speakers. If a number of changes point in a certain direction, that may indicate some 'psychological plausibility' for a particular generalisation. In other words, "diachronic data should be expected to corroborate, not contradict, postulations about synchronic structure" (Maiden 2001: 45). It is well known from the large debate on English verb inflection that the weak classes have been productive, diachronically. In Norwegian, although the weak classes have gained much more members, overall, both weak and strong classes have been productive, to some extent (cf. Nilsen 2012, also Venås 1967, 1974, Enger 1998, 2010), so diachronic productivity does not yield a clear-cut dichotomy between weak and strong.

Changes showing that the strong verb inflection is productive may 'go against the grain' of a number of morphological models, as many theorists tend to presuppose that 'strong' means 'irregular' (and 'diachronically recessive'), but changes that question our models can be found more often than we might think (cf. also Fertig 2013: 80-83, who makes the same point for English). In fact, such transitions turn out to be particularly common in Norwegian if the verb denotes a sudden, momentaneous, abrupt event - thereby indicating a link between strong inflection and semantics.

The background for looking at historical change in Norwegian is Old Norse, the 'mother language' as we suppose it to have been spoken (in Norway, on Iceland and the Faroe Isles) around 1200.Venås (1967) lists 128 verbs that can inflect as strong in present-day Norwegian (in some variety or another), but that were not attested in Old Norse. Of these, Nilsen finds that 34 , i.e. $26,5 \%$, can be classified as momentaneous. That is minimally higher than the percentage of strong verbs that can be thus classified, but considerably higher than the share of momentaneous verbs in the weak control group, in which only $9 \%$ can be classified as 
momentaneous (Nilsen 2012: 86). This means that strong inflection has been particularly productive for momentaneous verbs. ${ }^{6}$

Importantly, the fact that semantics has influenced inflection class does not mean that formal properties have not had any role; also phonological similarity has played a part - and this part may well be larger than that played by semantics. Our aim is not to deny the role of phonological motivation, but to show that semantics also plays a role.

The link with momentaneity appears to have been more important for one strong subclass, traditionally referred to as 'class III'. The strong sub-classes are characterised by phonological coherence, and by traditional accounts (such as Venås 1967), class III includes (somewhat simplified) the stressed vowels /e/, /i/ in the verb root in the infinitive and /a/ in the past. In other words, the class includes verbs as dette 'fall' (past tense datt), finne 'find' (past tense fann). The fact that one phonologically motivated sub-class has been particularly productive would indicate that semantic associations and phonological associations can work together.

Presumably, all grammatical theorists will concede that there can be a link between inflection classes and phonology. A link between inflection classes and semantics may seem more unexpected, but as long as we concentrate on noun inflection, it is well known that nouns denoting animate entities may display certain regularities setting them apart from other

\footnotetext{
${ }^{6}$ It is perhaps worth pointing out that the verb classes of Early Germanic were semantically motivated, to a certain extent, in that they were based on transitivity and aktionsart (cf. also Dammel 2011). There are such pairs of strong, intransitive verbs and derived transitive weak verbs as reflected in e.g. German fahren 'go' - führen 'lead', Norwegian flyte 'float' (the way a swimmer does) - fløyte 'cause to float' (the way one used to do with logs on a river).
} 
nouns. However, perhaps such examples may be less widespread in verb conjugation, as argued by Anderwald (2011: 262-263):

While extra-morphological motivation is quite frequent for nominal classes [...], at least semantic motivation is rarely observed in verbs. Phonological motivation seems to be a more plausible candidate, for, at least historically, Germanic strong verb classes seem to have been phonologically motivated.

This suggestion seems very reasonable (see also Dammel 2011: 149, 291ff and Enger 2010a: 374 for similar ideas). All the same, Norwegian shows semantic motivation for inflection classes in verbs - in a part of the grammar that we might have thought was fairly well charted.

\subsection{Supporting evidence}

There are other cases, both in Norwegian and in other Germanic languages, which show a link between the semantics of a verb and its conjugation class, thereby supporting the claim made above.

The first examples involve so-called 'pair verbs' (cf. Enger 1998: 130 and further references). In all Scandinavian languages, one finds morphologically related pairs of verbs, where one member is causative, transitive and inflects as weak, the other is non-causative, intransitive and inflects as strong. Examples are Norwegian henge 'hang (transitive, weak)' vs. henge 'hang (intransitive, strong)'; sitje 'sit (intransitive, strong)' versus setje 'set, place (transitive, weak)':

(1) Kjell hengde opp lua på knaggen vs. Lua hang på knaggen

'Kjell hung his cap on the hook' vs. 'The cap hung on the hook'

(2) Faren sette babyen fast $i$ stolen vs. Babyen sat $i$ stolen 
'The father fastened the baby in the chair' vs. 'The baby sat in the chair' Transitivity is, arguably, ultimately related to meaning, so this is a case where semantics and inflectional morphology connect.

A second set of examples involves the so-called expressive past tense (cf. also Enger 1998, Reitan 1930). In some dialects of Norwegian and Swedish, verbs that normally are weak can be inflected as strong if they denote an abrupt, sudden action, especially when used in comparative adverbial clauses. Compare koste 'to broom, to swipe'; we have rendered the examples in official Nynorsk orthography for better comparison:

(3) Kjell kosta golvet

'Kjell broomed/swiped the floor'

(4) Toget gjekk så det kost

'The train went so it whoosh'

Note again the link between 'strong' and momentaneous action. A similar phenomenon is found in certain Swedish dialects close to the border; cf. Dahlstedt (1962: 206).

There are other examples in Germanic of momentaneity being associated with strong or irregular, in the English terminology - inflection. For English, Quirk (1970) reports a link between durativity and the choice of $-t$ rather - $e d$ as a past tense marker; it turned out to be more likely that speakers (both British and American) should choose e.g. burnt over burned if the aspectual meaning intended was non-durative (compare also Tobin 1993).

For Swedish, Karlsson \& Sahlquist (1974: 77) report that if a verb has both an older strong and a newer weak form, then the weak form will in particular be used to express durative, iterative-frequentative meaning. It follows that momentaneous actions will be used with the strong form in particular. For example, while the Swedish verb skälva 'shiver, shake' in isolation can be inflected either as strong or as weak (past tense form either skalv or 
skälvde), Karlsson \& Sahlquist claim that the strong variant would be unacceptable in a sentence where an adverbial of time signals non-momentaneity. Thus, Hon låg och skälvde hela natten 'She lay shivering the whole night' is fine, while *Hon låg och skalv hela natten is unacceptable, according to Karlsson \& Sahlquist.

Another example of semantic motivation comes from German. The verb brauchen 'need; have to' has traditionally had a regular inflection, compare e.g. Er braucht einen Stuhl 'he needs a chair'. In current usage, however, in negated contexts, brauchen can be used without its suffix - $t$ in the 3. sg., compare er brauch nicht seine Schwester (zu) besuchen 'he need not visit his sister'. It seems reasonable to suppose that this innovation is motivated by the similarity that brauchen has with modals. ${ }^{7}$ Modals do not take the suffix $-t$ in the 3.sg., compare er muss (*musst) seine Schwester besuchen 'he must visit his sister'. (The possibility of leaving out $z u$ 'to' is probably also motivated by analogy to modals taking bare infinitives, cf. Er muss sie besuchen vs. Er wünscht sie zu besuchen 'he wishes to visit her'. See also Dammel 2011: 141-142.)

A perhaps less familiar example comes from German dialects in Switzerland and North Italy, where, according to Dammel (2011: 142ff.), conjugations are restructured partly on the basis of semantics. In the dialect of Lötschental, for instance, weak causative verbs tend to belong to one and the same conjugation, weak durative and inchoative verbs to others. ${ }^{8}$ When, in the early $20^{\text {th }}$ century, this fairly isolated community experienced more contact with other

\footnotetext{
${ }^{7}$ Already Wurzel (1984: 127) mentions the modals as an example of morphological characteristics becoming linked to extra-morphological characteristics, so that entropy is reduced; for a more recent discussion in English, see Simon \& Wiese (2011: 17-20).

${ }^{8}$ This is not an entirely new development, as a referee reminds us: The semantic class distinctions in Lötschental retain and systematise Old High German weak class distinctions.
} 
dialects and languages, speakers began to show some uncertainty and vacillation in conjugation class membership. Interestingly, the vacillation arose in particular where there was a 'mismatch' between semantic factors and inflection class membership. In this situation, it turned out to be more likely that speakers started inflecting a particular verb according to the pattern otherwise characteristic of its semantic properties.

It has been widely believed that 'strong' and 'weak' in Germanic is linked to form only; Nilsen's (2012) study of Norwegian, presented in brief here, may lead us to question this belief - which has also been questioned by Baayen \& Prado Martin (2005) and Ramscar (2002) for English.

\subsection{Summarising section 2}

A well-known insight from Natural Morphology, notably Wurzel (1984), is that speakers prefer inflection classes to be linked to properties of the words. Norwegian verb inflection comes out as less of an exception than we may have thought, since the distinction between strong and weak classes does have some semantic, i.e., extra-morphological motivation, in just the way that one would expect on the basis of Natural Morphology (and cognitive linguistics). ${ }^{9}$

However, cases where one inflection can be used in one set of circumstances, another in another set of circumstances, as in the case of the expressive past, is not what Natural

\footnotetext{
${ }^{9}$ By contrast, the interaction found between morphology and semantics on this point in Norwegian is of a kind that some generative models (though not all) would not lead us to expect; a number of such models emphasise modularisation (e.g. Newmeyer 1983, Pinker 1999). Also the case of inflection varying according to circumstances is unexpected in such frameworks.
} 
Morphology would lead us to expect. Also, the motivation uncovered in Norwegian verbs is not 'absolute', it is not a simple yes/no, but a tendency. Some decades ago, tendencies were more difficult to uncover in linguistics, and therefore, analysts envisaging motivation were more likely to see it as a binary (e.g. Wurzel 1984). Today, linguistics has become a more quantitative enterprise (cf. e.g. Siemund 2011), and we should try to incorporate tendential motivation into our models.

\section{Comparative constructions}

\subsection{The issue}

Many morphologists operate with a concept of 'prototypical' or 'canonical' inflection. Tense, which looms large in Section 2, is neither, as it is not syntactically determined. However, adjective comparison (aka gradation) is even less prototypical than is tense. It is not even obvious that comparison is inflection at all in Scandinavian languages; in the Danish reference grammar, Hansen \& Heltoft (2011: 185, 853ff) call it derivation. However, comparison is most often treated as inflection, for example in both the Norwegian and the Swedish reference grammars, and inflection classes are posited also for adjectives (Faarlund, Lie \& Vannebo, 1997: 350-360, Teleman, Hellberg \& Andersson 1999: 197-201), even if one of the two central classes is 'periphrastic', as we shall see. ${ }^{10}$

\footnotetext{
${ }^{10}$ Given that adjective gradation can be seen as 'inherent' inflection, the most 'derivationlike' kind of inflection, this differential treatment is not terribly surprising. A possible argument for derivation, according to Hansen \& Heltoft, is that the comparative changes the valency of the adjective, two possible arguments for inflection is that there is semantic
} 
For the adjectives, as for the verbs, it has long been recognised that there is a link between inflection class and form, more specifically phonological shape. By traditional accounts, adjectives that are monosyllabic in the positive tend to get an ere-comparative (aka synthetic or affixal inflection), adjectives that are polysyllabic in the positive will get a comparative with mer 'more' (analytic aka periphrastic). A number of other factors have been invoked - even etymology; it has been claimed that borrowed, Latinate adjectives will typically have analytic (periphrastic) comparison. Of course, these ideas are not taken out of the blue. Compare Table 2 below.

Table 2 Adjective comparison, Bokmål

\begin{tabular}{|l|l|l|l|}
\hline Positive & Gloss & Comparative & Superlative \\
\hline snill & 'kind, gentle' & snillere & snillest \\
\hline søt & 'cute' & søtere & søtest \\
\hline smart & 'smart' & smartere & smartest \\
\hline ny & 'new' & nyere & nyest \\
\hline sjarmerende & 'charming' & mer & mest \\
& & sjarmerende & sjarmerende \\
\hline
\end{tabular}

regularity (-ere always signals comparative) and that it is, after all, possible to construct syntactic contexts in which the comparative would be obligatory. 


\begin{tabular}{|l|l|l|l|}
\hline kreativ & 'creative' & mer kreativ & mest kreativ \\
\hline irriterende & 'irritating, annoying' & mer irriterende & mest irriterende \\
\hline underholdende & entertaining & mer & mest \\
& & underholdende & underholdende \\
\hline stor & & & \\
\hline tung & 'big, large' & større & størst \\
& & & tyngst \\
\hline
\end{tabular}

The etymology hypothesis may initially seem to account for the facts, and it is not only found in the Norwegian reference grammar (Faarlund, Lie \& Vannebo 1997: 357), but also in a study of comparison in Swedish (Nordberg 1982). It may seem somewhat surprising that the hypothesis has gone fairly unquestioned; in a context of structural or generative linguistics, in which we find both the Norwegian reference grammar and many others, one would not expect etymology to be relevant. In a synchronic description of the language, the etymological origin of words is usually taken to be irrelevant, and it seems implausible that language users should have knowledge of the etymology of all words.

In fact, invoking etymology turns out to be unnecessary (cf. Spilling 2012: 82). For example, it is often noted that a number of English loan-words are inflected periphrastically, such as bitchy, sexy. Yet the fact that they are inflected in this way need not have anything to do with their etymology, since they are phonologically and morphologically similar to recent 'native' Norwegian words that inflect the same way - e.g. Harry 'in a vulgar style', snacksy'nice, elegant'. After all, monosyllabic loan-words from English such as chill, $d \phi l l<d u l l$ 
inflect affixally, just as monosyllabic 'native' adjectives snill, vill 'wild' typically do - that does not indicate that etymological origin is particularly relevant. Similarly, it is often claimed that words that used to belong to another word-class inflect periphrastically, but Spilling shows that this category turns out to contain rather few members, and those members are phonologically rather similar to 'native' adjectives that also inflect periphrastically. While the empirical basis for a number of the claims about adjective inflection in the previous grammars (such as the relevance of etymology or previous word-class) may not be entirely clear, Spilling's (2012) study is based on a large corpus.

Examples (5) and (6) illustrate straightforward affixal ('synthetic') comparison; the comparative is used for comparison between two different entities:

(5) Haddock er snillere enn Allan ${ }^{11}$

'Haddock is kinder than Allan'

(6) Bianca Castafiore er søtere enn Rastapopoulos

'Bianca Castafiore is cuter than Rastapopoulos'

Examples 7 and 8 involve the analytic comparative:

(7) Tournesol er mer kreativ enn Dupont

'Tournesol is more creative than Dupont'

(8) Bianca Castafiore er mer sjarmerende enn Max Hansen

\footnotetext{
${ }^{11}$ In this paper, we stick to constructed examples, as they are easy to handle for present purposes. The studies on which we base our conclusions, however (Spilling 2012, Spilling \& Haugen 2013, 2014), are corpus-based.
} 
'Bianca Castafiore is more charming than Max Hansen'

These are examples where two entities are compared with respect to one property. Haddock scores better than Allan does with respect to the property of kindness, Bianca Castafiore scores better than Max Hansen does when it comes to the property of having charm.

In traditional descriptions, it is also often noted that for some adjectives, the analytic and the synthetic comparative appear to co-exist. For example, from the armchair linguist's point of view, we might note that for an adjective such as $g u l$ 'yellow', the two comparatives are possible, and they would seem to be functionally equivalent at first glance, cf. (9):

(9) gulere/mer gul

'more yellow'

This is a marked contrast to, say, the adjective sjarmerende 'charming', for which there is only one possible comparative; a priori, the alternative sjarmerendere is at least imaginable, but this is positively excluded, whether we wish to think of this constraint as morphophonological or as phonological, cf. $(10)^{12}$ :

mer sjarmerende/*sjarmerendere

'more charming'/*‘charming-er'

The case of gul does not only contrast with the adjective sjarmerende, but also with our general expectations. On the whole, we expect 'inflectional parsimony' (Carstairs 1987:

\footnotetext{
${ }^{12}$ An anonymous reviewer asks the interesting question whether adjectives that do not have a synthetic comparative, such as sjarmerende, should be seen as defective. We would say 'no'. Such adjectives can undergo comparison - except for the absolute comparison, which is used with a minority of adjectives anyway.
} 
31-32); we expect each 'cell' in a paradigm to be filled by one and only one 'cell-mate'. ${ }^{13}$ In

3.3 below, we return to this issue and argue that (9) is less problematic than it may seem.

\subsection{Meta-comparison}

Ordinary comparison typically involves two different entities being compared for one and the same property, for example Tournesol and Dupont with respect to creativity in (7) above. ${ }^{14}$ This is not the only thing we can do with comparison, though. In so-called meta-comparison (see also Spilling \& Haugen 2014), one entity is compared to itself with respect to two different properties, as in (11):

(11) Tournesol er mer underholdende enn irriterende

'Tournesol is more entertaining than [he is] irritating'

In example (11), Tournesol is compared with himself; what is at issue, is if he scores better on being entertaining or on being irritating. The reason for the term 'meta-' is that one characterises the aptness of what is said - "it is more fitting to say of Tournesol that he is entertaining than to say that he is irritating". Therefore, on this point, the principle of 'division of labour' holds to an even higher degree than traditionally assumed.

Firstly, in meta-comparison, the analytic or periphrastic comparative is the only possibility. That is, adjectives are inflected differently in meta-comparison than in ordinary

13 'Over-abundance' can clearly be found (cf. Thornton 2011), but it is not the norm.

${ }^{14}$ An anonymous referee rightly points out that this holds for the comparative, and not for the superlative, but then, it is the comparative, not the superlative, that is our main focus in this paper. 
comparison. Example (11) may not seem terribly surprising, since we find polysyllabic adjectives, one even of Latinate descent (irriterende), being inflected analytically. Examples (12) and (13) bring out the point more clearly, as $s \phi t$ and snill are monosyllabic in their base form and of native origin and so normally inflect as in Table 2. Yet in meta-comparions, they inflect by means of mer, cf. $(12,13)$ :

(12) Terry er mer søt enn trassig

'Terry is more cute than stubborn'

(13) Haddock er mer snill enn smart

'Haddock is more kind than smart'

In meta-comparison, then, even adjectives that normally inflect synthetically, by means of the ere-suffix, take analytic (aka periphrastic) inflection.

In one sense, meta-comparison is for the adjectives what the 'expressive past tense' in Section 2 is for the verbs: In both cases, a lexeme has a particular inflection in a particular syntactic/semantic context, another in other contexts. In meta-comparison, analytic inflection is used even for adjectives that normally inflect synthetically, in expressive past tense, strong inflection is used even for verbs that normally inflect as weak.

Importantly, 'textbook examples' of meta-comparison such as $(12,13)$ are completely absent from Spilling's corpus (2012: 104). What she does find in her corpus, however, is examples like (14b); we have constructed a small dialogue:

a. Ville du kalle Terry dum?

'Would you call Terry stupid?' 
b. Nei, Terry er mer søt.

'No, Terry is more cute.'

Without context, example (14b) would seem to support the conclusion indicated by example 9; viz., that there is random variation (since the normal comparative of $s \phi t$ is sфtere). But this is in fact not at all the case, as shown by Spilling. Examples that at first sight indicate productivity of analytic inflection - such as (14b) - are (at least in the overwhelming majority of cases) examples of meta-comparison without the context clearly spelled out.

Furthermore, while meta-comparison triggers analytic inflection, there is an equally clear preference for synthetic inflection in so-called absolute comparison. These are examples such as $15-16$ :

(15) Møllenborg er en større herregård

Møllenborg is a big.COMP mansion

'Møllenborg is a large mansion'

(16) Ifølge nyere forskning er Syldavia et Belgia i forkledning

According-to new.COMP research is Syldavia a Belgium in disguise

'According to recent research, Syldavia is a Belgium in disguise'

There is no explicit second entity, as in canonical comparison, and there is no second property, as in meta-comparison. In Norwegian, absolute comparison has a literary, even bookish flavour, and it is restricted to a small number of adjectives. (There are clear parallels in German.) Polysyllabic adjectives, which typically do not allow a comparative in -ere, do not normally occur in cases of absolute comparison in Norwegian. By absolute comparison, the property denoted by the adjective need not hold to quite so large an extent as usual. In (15), Møllenborg does not have to be really big, by the standard for mansions. The research mentioned in example (16) does not have to be absolutely new; it is sufficient that it is fairly new. 


\subsection{A warning against introspection}

It has been widely held that many adjectives can take either comparative form, as illustrated with the example 'yellow' gul, in (9) above. For example, the Norwegian reference grammar says there "is no clear distinction between adjectives that can be inflected in one way or the other [i.e. synthetically or analytically]. Many can be inflected either way" (Faarlund, Lie \& Vannebo 1997: 356, our translation). ${ }^{15}$ They exemplify this with gul. On closer inspection, the claim does not quite hold; of all 635 adjective lexemes (distributed over 20,448 occurrences) in Spilling's (2012) corpus, only $12 \%$ are attested with both possible comparatives. The claim that there is no clear difference between the two groups and that many adjectives can be inflected either way therefore seems overstated; $88 \%$ of the adjectives in the corpus occur with only one comparative.

This illustrates a methodological danger of relying on introspection. By means of introspection, we can find out that grammatical synonymy is possible. Our point is not to dismiss introspection; indeed, (9) shows that there is some justification for the procedure. What recent technology and corpus linguistics helps us see, however, is that at least in this case, the synonymy is not so common in actual language use, since it is only found in $12 \%$ of the adjectives. It is very unlikely that introspection could help us see such a point. In isolation, example (14b) seems to support the assumption of an 'arbitrary choice of variants' (since the normal comparative of $s \phi t$ would be sфtere, and not mer $s \phi t)$. However, an example like (14b) does not occur in isolation. In cases of analytic comparatives (such as (14b)), part of the meta-

\footnotetext{
${ }^{15}$ In the original: "Det er ikke noe klart skille mellom adjektiver som bøyes på den ene, og dem som bøyes på den andre måten. Mange kan bøyes på begge måter.”
} 
comparison is usually either implicit or found somewhere in the surrounding context. (In the latter case, a question, as in (14a), is one of several options.)

In short: There is a division of labour. Not only do we typically find different inflections with different lexemes, but even when a lexeme opens for two variants, speakers find motivation for grammatical variation; speakers' use of variants is, again, not arbitrary. It is commonly assumed that the analytic comparative is younger than the synthetic one. In such cases, grammaticalisation theorists may talk of 'layering' (Hopper \& Traugott 2003: 124126), and it is typical of layering that there should be some kind of 'division of labour', as is the case for comparison in Norwegian.

\subsection{A comparison with two other studies on comparison}

Comparison in two related Germanic languages has been the topic of two important studies in recent years, Mondorf (2009), who discusses English, and Hilpert (2010), who discusses Swedish and English. There are some intriguing differences in the results, which may briefly be commented upon here.

Mondorf (2009) suggests a complexity hypothesis - a cognitively complex syntactic context should favour the less complex alternative, which in her view is periphrastic comparison. ${ }^{16}$ This complexity hypothesis is apparently not applicable for Swedish. According to Hilpert (2010), if there is an infinitive following the comparative in Swedish, the affixal comparative tends to be preferred (in $94 \%$ of the cases studied by Hilpert).

\footnotetext{
${ }^{16}$ This may perhaps be compared to the classical structuralist idea that we expect the unmarked alternative to emerge in marked contexts.
} 
This would seem to indicate that also the concept of 'construction' is relevant for the choice between the different comparatives. Norwegian data support this idea: The adjective ner 'near' is normally inflected affixally, which is unsurprising, given its phonological shape. In Spilling's corpus, there are 136 affixal comparatives of this adjective, one single periphrastic comparative. This one hit turns out to be in the idiomatic construction ta seg nar $a v$, literally 'take oneself near of', which means 'feel sorry about, be sore about'. Again, we illustrate with constructed examples:

$$
\text { Den store apen var nærmere nå }
$$

'The big monkey was closer now'

(18) Haddock tok seg mer nær av dette enn noen hadde trodd

'Haddock felt more sorry about this than anybody had expected'

Such findings indicate that the particular construction in which the adjective occurs may be relevant for the choice of periphrastic vs. analytic comparative. Sceptics may argue that one isolated example out of 137 need not mean terribly much, but such an objection implicitly suggests that it is accidental that the exception should be exactly where it is; also, searches in a larger corpus indicate that in this particular construction, the periphrastic comparative is preferred (see Spilling 2012: 92). Furthermore, by our intuition, it would be at least very unconventional - perhaps even ungrammatical - to use a periphrastic comparative in (17) or a suffixal one in (18).

This supports Hilpert's (2010) claim that Mondorf's complexity principle can hardly be the only factor explaining which kind of comparison is chosen. There is no independent argument why, say, ta seg naer av can be said to be a 'more complex' construction than e.g. komme naer innpå livet, literally 'come near into life-def.sg', meaning 'get more personal', yet 
the first takes a periphrastic comparative, the second an affixal one. Another observation indicating that the complexity principle does not account for everything is that in Swedish, affixal inflection is particularly common in cases where an element is repeated (Hilpert 2010: 37-38), more common than is periphrastic inflection.

(19) De klättrade högre och högre (Swedish

'They climbed higher and higher'

In examples such as (19), where the comparative is repeated, there is a clear preference in Swedish for affixal inflection. The preference is clearer in Swedish than in English, according to Hilpert. This does not square well with what Mondorf (2009) argues, in as much as it seems unreasonable to suppose that a syntactic context of repetition is less complex than one without. $^{17}$

\section{Conclusions}

Our conclusions are as follows. In Norwegian, the distinction between 'strong' and 'weak' verb conjugation is not only partly motivated by phonology, but also by semantics. 'Strong' verbs tend to be linked to a 'momentaneous' or 'expressive' meaning. The arbitrariness of the two classes has been overstated; even if we cannot claim that the distribution of the two classes is entirely predictable, it is not completely arbitrary, either. In the adjective comparison, there is a similar preference for not distributing grammatical variants arbitrarily:

\footnotetext{
${ }^{17}$ While Mondorf's complexity approach does not, in our view, account for everything, it certainly does not follow that it does not account for anything. For instance, the suggestion that there are phonological factors at work dividing classes of adjectives with and without the synthetic option makes sense for Norwegian - as for English.
} 
The 'periphrastic' and the 'affixal' inflection are typically used with different adjectives; it is only in a minority of cases that they overlap. Moreover, for those adjectives that allow either, the two have their different special areas, as it were: In cases of meta-comparison, only the periphrastic inflection is used, in cases of absolute comparison, only affixal inflection is used. ${ }^{18}$ Admittedly, meta-comparison and absolute comparison are both rather infrequent compared to 'canonical' comparison, but the point remains - it is in a minority of cases that 'affixal' and 'periphrastic' inflection overlap.

The studies of verb conjugation and adjective comparison also point, if indirectly, to a problem with the emphasis on 'morphomes', or autonomous morphology, that has arisen in the wake of Aronoff (1994). While the search for autonomous morphology has been valuable, it is also often helpful to look for motivation behind cases of grammatical variation. In this respect, our argument underscores a point made by Vincent (2013: 118), who sees a "danger that we will slip from arguing that morphology may at times display autonomous properties to treating morphology as an intrinsically autonomous domain . .. Inflectional systems may display autonomous properties but they are not insulated from the remainder of the linguistic system, and ... often ... motivated by the properties of other parts of that system". 19

\footnotetext{
${ }^{18}$ This state of affairs may be compared to partial synonymy in lexical semantics. For example, the English words faith and belief can both be used about religious persuasion, while one can have faith only in other people (not ?have belief in John); convictions are held to the best of my belief (not ?to the best of my faith).

${ }^{19}$ Recently, Dammel $(2011: 161)$ has taken issue with the idea that the Germanic preterite 'dental suffix' be 'purely morphomic'; she argues that there is a semantic reason why the past
} 
On the other hand, the fact that 'strong' is tendentially linked to both phonological and semantic motivation underscores an important observation that has been made repeatedly in more recent research; that morphomes may be gradient (Esher 2013, Maiden 2013); that although they are demonstrably not reducible to factors outside of morphology, they may still be related to factors outside of morphology.

Motivation behind grammatical variants may be even more widespread than traditionally assumed. This motivation need not come in the shape of a simple absolute dichotomy. There can be tendencies at work, as both the verb conjugation and the adjective comparison indicate in Norwegian. It is time to recognise that sensitivity to probability may be intrinsic to human language, cf. Baayen \& Prado Martin (2005). Both for the adjectives and the verbs, it seems to be the case that the language users' choice of variant in inflection interacts with semantics, pragmatics, syntax, in ways that had not been recognised before.

\section{References}

Anderwald, Lieselotte. 2011. Are non-standard dialects more 'natural' than the standard? A test case from English verb morphology. Journal of Linguistics 47(2): 251-274. Aronoff, Mark. 1994. Morphology by itself. Cambridge, MA: MIT Press.

participle and the past should have formal properties in common. Our point is not to take a stand in the debate, but if Dammel is right, this is another example of how the hunt for purely morphomic entities can lead us to overlook semantics. (In other words, the argument for a particular pattern being morphomic is always simply that there is no other account for it (cf. Aronoff 2012: 37), and this means that morphomic status is always provisional.) 
Aronoff, Mark. 2012. Morphological stems: What William of Occam really said. Word Structure 5(1): 28-51.

Baayen, R. Harald \& Fermín Moscoso del Prado Martín. 2005. Semantic Density and PastTense Formation in Three Germanic Languages. Language 81(3): 666-698.

Bjerkan, Kirsten Meyer. 2000.Verbal Morphology in Specifically Language Impaired Children [Acta Humaniora 73]. Oslo: Unipub.

Carstairs, Andrew. 1987. Allomorphy in Inflexion. London: Croom Helm.

Chomsky, Noam A. 1986. Knowledge of language. New York: Praeger.

Clark, Eve. 1993. The lexicon in acquisition. Cambridge: CUP.

Dahlstedt, Karl-Hampus. 1962. Det svenska Vilhelmina-målet: språkgeografiska studier över ett norrländskt nybyggarmål och dess granndialekter 2. Uppsala : Lundequistska bokh.

Dammel, Antje. 2011. Konjugationsklassenwandel [Change of conjugation class] [Studia Linguistica Germanica 103]. Berlin: Mouton de Gruyter.

Enger, Hans-Olav. 1998. The classification of strong verbs in Norwegian with special reference to the Oslo dialect: a study in inflectional morphology [Acta Humaniora 26]. Oslo: Scandinavian University Press.

Enger, Hans-Olav. 2010a. How do words change inflection class? Diachronic evidence from Norwegian. Language Sciences 32(3): 366-379. doi:10.1016/j.langsci.2009.07.005

Enger, Hans-Olav. 2010b. Partial and competing motivations for gender. Germanistische Linguistik 206-209 [=Kontrastive Germanistische Linguistik, utg. Antje Dammel, Sebastian Kürschner, Damaris Nübling], s. 673-693. 
Esher, Louise. 2013. Future and conditional in Occitan: a non-canonical morphome. In The boundaries of pure morphology: Diachronic and synchronic perspectives [Oxford Studies in Diachronic and Historical Linguistics 4], Silvio Cruschina, Martin Maiden \& John Charles Smith (eds), 95-116. Oxford: OUP.

Faarlund, Jan Terje, Lie, Svein \& Vannebo, Kjell Ivar. 1997. Norsk referansegrammatikk [Norwegian Reference Grammar]. Oslo: Universitetsforlaget.

Fertig, David. 2013. Analogy and morphological change. Edinburgh: Edinburgh UP.

Hagen, Jon Erik. 1994. Svake verb på -Vde og -Vte i bokmål og deres paradigmetilhørighet [Weak verbs in -Vde and -Vte in Bokmål and their inflection class membership]. In Helsing til Lars Vassenden på 70-årsdagen, Johan Myking, Helge Sandøy \& Ivar Utne (eds), 57-67. Bergen: Nordisk institutt.

Hansen, Erik \& Heltoft, Lars. 2011. Grammatik over det danske sprog [Grammar of the Danish language]. Odense: Syddansk Universitetsforlag.

Hilpert, Martin. 2010. Comparing comparatives: A corpus-based study of comparative constructions in English and Swedish. In Contrastive studies in construction grammar, Hans C. Boas (ed), 21-41. Amsterdam: John Benjamins.

Hopper, Paul J. \& Traugott, Elizabeth Closs. 2003. Grammaticalization. 2nd edn. Cambridge: CUP.

Karlsson, Fred \& Åsa Sahlquist. 1974. Starka verb i förvandling [Strong verbs in change]. Nysvenska studier 54: 44-83.

Maiden, Martin. 2001. What sort of thing is a derivational affix? In Yearbook of Morphology 1999, Geert E. Booij \& Jaap van Marle (eds), 25-52. Dordrecht: Kluwer. 
Maiden, Martin. 2013. 'Semi-autonomous' morphology. In The boundaries of pure morphology: Diachronic and synchronic perspectives [Oxford Studies in Diachronic and Historical Linguistics 4], Silvio Cruschina, Martin Maiden \& John Charles Smith (eds), 24-45. Oxford: OUP.

Mondorf, Brita. 2009. More support for more-support: The role of processing constraints on the choice between synthetic and analytic comparative forms. Amsterdam: John Benjamins.

Newmeyer, Frederick J. 1983. Grammatical theory: its limits and its possibilities. Chicago: University of Chicago Press.

Nicolay, Nathalie. 2007. Aktionsarten im Deutschen: Prozessualität und Stativität [Actionality in German: Processuality and stativity] [Linguistische Arbeiten 514]. Tübingen: Niemeyer.

Nilsen, Marianne Brodahl. 2012. Sterke verb og semantiske fellestrekk: Om semantisk motivasjon for bøyingsklassetilhørighet ved norske verb [Strong verbs and semantic commonalities: On semantic motivation for inflection class membership in Norwegian verbs]. MA thesis, University of Oslo. Downloadable at https://www.duo.uio.no/handle/10852/26739

Nordberg, Bengt. 1982. Vad händer med adjektivets endelseskomparation? [What happens with the adjective's suffixal comparison?] In Förhandlingar vid trettonde sammankomsten för att dryfta frågor rörande svenskans beskrivning, Hanaholmen 1981, Mirja Saari \& Marika Tandefelt (eds), 228-248 Helsinki.

Pinker, Stephen. (1999). Words and rules: the ingredients of language. London: Weidenfeld and Nicolson. 
Quirk, Randolph. 1970. Aspect and variant inflection in English verbs.

Language 46(2): 300-311.

Ramscar, Michael. 2002. The role of meaning in inflection: why the past tense does not require a rule. Cognitive Psychology 45(1): 45-94.

Reitan, Jørgen. 1930. Interjeksjonsverber i norske målføre [Interjection verbs in Norwegian dialects]. Maal og Minne 65-98.

Siemund, Peter. 2011. Universals and variation: an introduction. In Linguistic Universals and Language Variation [Trends in Linguistics Studies and Monographs 231], Peter Siemund (ed), 1-21. Berlin: De Gruyter Mouton.

Simon, Horst \& Wiese, Heike. 2011. What are exceptions? And what can be done about them? In Expecting the Unexpected: Exceptions in Grammar [Trends in Linguistics Studies and Monographs 216], 3-30. Berlin: De Gruyter Mouton.

Spilling, Eivor Finset. 2012. Gradbøying i norsk: En korpusbasert undersøkelse av talespråk [Comparison in Norwegian: a corpus-based study of spoken language]. MA thesis, University of Oslo. Downloadable at https://www.duo.uio.no/handle/10852/35125

Spilling, Eivor Finset \& Haugen, Tor Arne. 2013. Gradbøying i norsk: en bruksbasert tilnærming [Comparison in Norwegian: a usage-based approach]. Maal og Minne, 2013/2, 1-40.

Spilling, Eivor Finset \& Haugen, Tor Arne. 2014. Meta-komparasjon i norsk. Norsk Lingvistisk Tidsskrift 32(1): 3-29.

Teleman, Ulf, Hellberg, Staffan \& Andersson, Erik. 1999. Svenska Akademiens Grammatik 2: Ord [The Swedish Academy Grammar vol. 2: Words]. Stockholm: Norstedts. 
Thornton, Anna M. 2011. Overabundance (multiple forms realizing the same cell): a non-

canonical phenomenon in Italian verb morphology. In Morphological autonomy: perspectives from Romance inflectional morphology, Martin Maiden, John Charles Smith, Maria Goldbach \& Marc-Olivier Hinzelin (eds), 358-382. Oxford: OUP.

Tobin, Yishai. 1993. Aspect in the English verb: Process and result in language. London: Longman.

Vendler, Zeno. 1967. Verbs and times. In Zeno Vendler, Linguistics in philosophy, 97-121. Ithaca, NY: Cornell University Press.

Venås, Kjell. 1967. Sterke verb i norske målføre [Strong verbs in Norwegian dialects]. Oslo: Universitetsforlaget.

Venås, Kjell. 1974. Linne verb i norske målføre [Weak verbs in Norwegian dialects]. Oslo: Universitetsforlaget.

Vincent, Nigel. 2013. Compositionality and change in conditionals and counterfactuals in Romance. In The boundaries of pure morphology: Diachronic and synchronic perspectives [Oxford Studies in Diachronic and Historical Linguistics 4], S. Cruschina, M. Maiden \& J.C. Smith (eds), 116-137. Oxford: OUP.

Wurzel, Wolfgang Ullrich. 1984. Flexionsmorphologie und Natürlichkeit [Inflectional morphology and naturalness] [Studia Grammatica xxi]. Berlin (GDR): AkademieVerlag. 